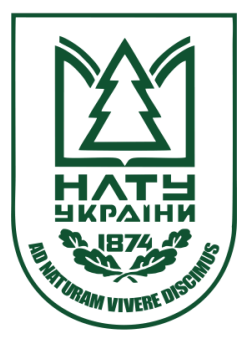

Науковий вісник НЛтУ України Scientific Bulletin of UNFU

ISSN 1994-7836 (print)

http://nv.nltu.edu.ua

https://doi.org/10.15421/40280413

Article received 08.02.2018 p.

Article accepted 26.04.2018 p.

Correspondence author

M. A. Kalnutska

УДК 323:364.14

М. А. Кальницька

Ужсгородський національний університет, м. Ужгород, Украйна

\title{
СУБ'ЄКТИ РЕАЛІЗАЦІЇ ДЕРЖАВНОЇ ПОЛІТИКИ СОЦІАЛЬНОГО РОЗВИТКУ
}

Розглянуто суб'єкти реалізації державної політики соціального розвитку. Зважаючи на ефективність реалізації державної політики соціального розвитку, важливою є характеристика тих інституцій, які розробляють та впроваджують соціальні програми. Зазначено, що об'єкти та суб'єкти державної політики соціального розвитку характеризуються різноманітністю, а їх особливості залежать від багатьох чинників. Поряд з існуванням потужного соціального інституту в особі державних органів, важливим для покращення державної політики соціального розвитку є підвищення ролі недержавних організацій. Визначено особливість впливу діяльності громадських організацій на реалізацію державної політики соціального розвитку. Якщо на макрорівні головним суб'єктом державної політики соціального розвитку виступає держава, то на мезорівні - органи регіональної влади, а на мікрорівні - особа та сім'я. За існування ієрархічної взаємозалежності між суб'єктами регулювання, суб'єкти нижчого рівня стають об'єктами політики, що проводиться суб'єктами вищого рівня. Зроблено висновок про те, що соціальна політика є однією з найважливіших функцій будь-якої держави, а особливості діяльності суб'єктів державної політики соціального розвитку на сучасному етапі та в сучасних умовах, із залученням громадського сектору, полягають у мінімізації функцій оперативного втручання в різні сфери життя, способи та форми реалізації людиною свого потенціалу.

Ключові слова: суб'єкт; державна політика; соціальний розвиток; державні органи; соціальні програми; недержавні організації.

Вступ. Соціальна політика є однією 3 найважливіших функцій будь-якої держави. У загальному розумінні державна політика соціального розвитку виступає системою, до складу якої входять не тільки інституційні, а й понадінституційні (ті, що належать до відповідальності інших соціальних інститутів) суб'єкти різних форм власності та видів діяльності, об'єднаних однією спільною метою - забезпечення соціального розвитку, створення умов для всебічної самореалізації соціального потенціалу людини та соціальних груп і суспільства загалом.

Тому, зважаючи на ефективність реалізації державної політики соціального розвитку, важливою є характеристика тих інституцій, які розробляють та впроваджують соціальні програми.

Аналіз останніх публікацій і досліджень. Питання, які стосуються суб'єктів реалізації державної політики соціального розвитку, досліджували такі вчені як: С. I. Богуславська (2013), В. І. Когут (2015), А. Колот (2011), Ю. М. Уманців (2010), Н. Ю. Сабіна (2014), О. В. Макарова (2015), О. Ткач (2013), О. І. Іляш (2012) та ін.

Метою роботи $є$ питання щодо діяльності суб'єктів реалізації державної політики соціального розвитку.

Викладення основного матеріалу. Кожен із видів суб'єктів, що беруть участь у реалізації державної політики соціального розвитку, регламентує свою діяльність конкретними соціальними інтересами, нормами, правилами та стандартами, закріпленими нормативноправовою базою. Цими суб'єктами є (залежно від форм власності, способів та рівня реалізації своєї діяльності)

державні органи влади, органи місцевого самоврядування, недержавні організації, громадські асоціації, союзи та об'єднання (Kogut, 2015). Чіткого переліку суб'єктів державної політики соціального розвитку немає, а окремі науковці чи групи до суб'єктів соціальної політики відносять різні інституції, проте основним суб'єктом її реалізації є держава, яка визначає загальні засади, мету, завдання, пріоритети, нормативно-правову базу й проводить роботу з їі реалізації.

Зауважимо, що інститути державної політики соціального розвитку, як суспільні інститути, характеризується:

- визначеною метою своєї діяльності;

- функціями для досягнення визначеної мети;

- характерною для цього інституту соціальною позицією;

- системою правил, стимулів і санкцій, які унормовують поведінку всіх суб'єктів соціальної дії, визначають форми і засоби задоволення їхніх інтересів, усувають або пом'якшують конфлікти (Orlova, Sabina \& Verovina, 2014).

Зважаючи на ефективність реалізації державної політики соціального розвитку, важливою є характеристика тих інституцій, які розробляють та впроваджують соціальні програми, тобто суб'єктів державної політики соціального розвитку. Багатовекторність суспільних відносин і неоднорідність соціальної сфери зумовлюють складну структуру суб'єктів державної політики соціального розвитку, до яких найчастіше входять такі:

1. Громадянин (людина, особистість).

2. Держава (система державних інституцій).

3. Громадянське суспільство загалом (політичні партії,

\section{Інформація про авторів:}

Кальницька Марина Анатолівна, канд. екон. наук, доцент, кафедра міжнародної політики. Email: iraan@ukr.net

Цитування за ДСТУ: Кальницька М. А. Суб'єкти реалізації державної політики соціального розвитку. Науковий вісник НЛтУ

України. Серія Економічна. 2018, т. 28, № 4. С. 74-77

Citation APA: Kalnutska, M. A. (2018). Subjects of Implementation of Public Policy of Social Development. Scientific Bulletin of UNFU, 28(4), 74-77. https://doi.org/10.15421/40280413 
об'єднання, рухи, громадські організації, фонди, асоціації, союзи, спілки громадян).

Часто до суб'єктів державної політики соціального розвитку відносять також роботодавців та підприємців, особливо зважаючи на розвиток такої категорії, як соціальна корпоративна відповідальність. Очевидно, що ключовою фігурою у процесі впровадження державної політики соціального розвитку є людина, тому під час розроблення соціальних програм потрібно усвідомити те, що ця складова державного регулювання формується для людини, заради забезпечення іiї інтересів, i будуть впроваджувати також люди (Tcach, 2013). Хоча держава є найвагомішим суб'єктом державної політики соціального розвитку, проте досить неоднозначним, і в певних умовах може виступати неефективним суб'єктом, стримувачем повноцінного процесу соціального розвитку.

Незважаючи на це, за певних умов, наприклад, під час мумпільних потрясінь та перетворень, роль держави $\epsilon$ головною в регулюванні соціальних процесів і саме вона повинна забезпечити створення умови для оптимального соціального розвитку. Попри те, держава не може нав'язувати спосіб чи підхід до вирішення соціальних проблем (Boguslavska \& Potapenko, 2013), а повинна тільки бути платформою для формування належних умов соціального розвитку, враховуючи особливості конкретних соціальних спільнот, їх традиції та менталітет, етнічний склад населення та інші особливості регіонального розвитку чи специфічні характеристики. Державна політика забезпечення соціального розвитку повинна насамперед акцентувати уваги не на нав'язуванні певної моделі, а на створенні умов для повноцінного залучення кожного громадянина до формування громадянського суспільства, де існує баланс між інтересами громадянина та держави, а людина може в такий спосіб позбутися залежності від держави та їі структур. Подібна форма співпраці громадянина, громадянського суспільства і держави почала формуватися в Україні після Революції гідності та закріплюється з розвитком процесів децентралізації, де через повноваження, надані територіальним громадам, відбувається наділення громадян та суспільних об'єднань реальними важелями впливу на формування та реалізацію політики в соціальній сфері.

Розглядаючи докладніше суб'єкти державної політики соціального розвитку, варто розкрити розуміння суті поняття "суб'єкт", як: суб'єкт соціальний - індивід або соціальна спільнота, яка спрямовує на зовнішній світ своє пізнання і дію (Umanciv, Minyilo \& Kosik, 2010). Перетворення індивіда чи спільноти на суб'єкт відбувається через взаємодію з іншими людьми у процесі спільної діяльності. Отже, у соціальній сфері суб'єктами можуть бути ті, хто їі реалізовує - соціальні працівники, волонтери, державні та недержавні соціальні служби, благодійні організації тощо.

Отже, робота в соціальній сфері $\epsilon$ своєрідною взаємодією об'єкта та суб'єкта для допомоги людям/спільнотам у вирішенні їх життєвих проблемних ситуацій, забезпеченні належного рівня життя та задоволенні потреб. Керівну та координуючу роль у цьому процесі відіграє держава, створюючи систему соціальних установ, організацій та інституцій. У наукових колах поширений розподіл соціальних інституцій за різними критеріями, зокрема, за масштабом діяльності: міжнародні; національні та місцеві (їх вплив поширюється на невеликий район - відділи центру зайнятості населення, територіальні центри соціальної допомоги). Наступним є розподіл за рівнями функціонування.

В Україні існує широка інституційна база державної політики соціального розвитку, обумовлена спрямованістю на вирішення багатьох проблем соціального життя, куди входять: Міністерство праці та соціальної політики, Пенсійний фонд, Міністерство охорони здоров'я, Міністерство освіти і науки, Вища атестаційна комісія (Атестаційна колегія), Державний комітет у справах сім'ї та молоді, Міністерство надзвичайних ситуацій, Міністерство внутрішніх справ, Державна пенітенціарна служба України, функції якої в 2016 р. переклали на Міністерство юстиції; місцеві держадміністрації (Ilyash, 2012).

Об'єднавши перелік суб'єктів державної політики соціального розвитку як реалізаторів програм, спрямованих на вирішення проблем соціально-трудової сфери, виокремимо такі групи, від найнижчого до найвищого рівнів: людина, держава, суспільство, громадські організації, політичні партії, підприємці, роботодавці, соціальні спільноти. Головним суб'єктом соціальної політики $\epsilon$, проте, сама соціальна держава, яка наділена характеристиками, що їх О. Ткач у своїй праці "Особливості державної політики у сфері соціального розвитку України", виокремив як такі: 1) відмовляється від уніфікованості та оперативного втручання у виконання соціальних програм; 2) використовує диференційовані підходи, враховує унікальність шляхів вирішення проблем і суперечок у соціальній сфері; 3) випереджує прояви деструктивного та неефективного перебігу соціальних процесів та явищ; 4) створює умови, необхідні для розвитку та реалізації особистісного потенціалу людини (Tcach, 2013).

Роль держави як центрального суб'єкта державної політики соціального розвитку значною мірою підкріплюється роллю інститутів громадянського суспільства, яким держава делегує широкий спектр функцій, які включають, окрім суб'єктів і об'єктів, принципи, інститути й механізми.

Специфікою ролі держави є іiі відповідальність за соціальну стабільність у суспільстві, стабільність соціального стану громадян, соціальних груп, стимулювання прогресивного розвитку суспільства, що виходить із самої природи держави як єдиного суб'єкта, що наділений усім спектром політичних і правових повноважень.

Соціальні відносини та процеси, що відбуваються в суспільстві, по-різному впливають на формування соціальної безпеки, задоволення соціальних потреб $\epsilon$ об'єктом державної політики соціального розвитку. Підставою є забезпечення чіткого, злагодженого функціонування суспільно-політичних інститутів, координації діяльності системи для напрацювання оптимального співвідношення дій усіх іiї учасників, форм, способів і заходів соціальної політики держави (Orlova, Sabina \& Verovina, 2014). У повноцінному, активному громадянському суспільстві державна політика соціального розвитку здійснюється в багатосуб'єктному середовищі, і тільки після належної взаємодії держави з усіма суб'єктами громадянського суспільства формуються іiі загальні цілі та ключові положення.

Об'єкти та суб'єкти державної політики соціального розвитку характеризуються різноманітністю, а їх особ- 
ливості залежать від багатьох чинників. Такими чинниками можуть бути: існуюча структура органів соціальної роботи, професійна ситуація, специфіка проблем особистості, обрана модель професійної діяльності, рівні здійснення соціальної роботи (індивідуальний, груповий, суспільний тощо) та ін. (Makarova, 2015). Суб'єктами, що належать до сфери державного управління, є державні та позадержавні структури, які діють у соціальній сфері, а загалом суб'єктом можна розглядати й усе населення країни, що творить її соціум (Orlova, Sabina \& Verovina, 2014). У зарубіжній науковій літературі трапляються підходи, що розглядають ринок зайнятості, трудові відносини та систему соціального захисту населення як основні об'єкти соціальної політики (Kolot, 2011), що тільки підкреслює всю багатоаспектність суб'єктно-інституційного забезпечення регулювання соціальної сфери.

Поряд з існуванням потужного соціального інституту в особі державних органів, важливим для покращення державної політики соціального розвитку є підвищення ролі недержавних організацій. У сучасний період посттрансформаційного розвитку саме вони здатні істотно докластися до розвитку системи соціального забезпечення, оскільки пропонують новаторські моделі та підходи до роботи та мають змогу залучати допомогу 3 боку міжнародних організацій та інституцій соціальної сфери. Позитивний вплив на соціальну сферу держави матиме налагодження партнерських відносин між державними органами та інститутами громадянського суспільства через спільне планування та координацію дій цих двох секторів соціальної політики (Kogut, 2015).

Особливість впливу діяльності громадських організацій на реалізацію державної політики соціального розвитку полягає в тому, що вони здатні, завдяки власній чітко окресленій специфіці та вмінню глибше проникнути у вирішення конкретних завдань, оптимізувати процес реалізації соціальних функцій. Вони, на відміну від державних органів, є динамічнішими та гнучкішими у своїх діях та методах праці. Саме наявність громадянського суспільства дає змогу істотно підвищувати рівень людського потенціалу та соціальної захищеності громадян.

Висновки. Отже, якщо розділити державні та недержавні структури, що є суб'єктами реалізації державної політики соціального розвитку, можна виокремити по- зитивні сторони кожної з груп, що, взаємодоповнюючись, творять потужний механізм соціального забезпечення в державі.

Якщо на макрорівні головним суб'єктом державної політики соціального розвитку є держава, то на мезорівні - органи регіональної влади, а на мікрорівні - особа та сім'я. За існування ієрархічної взаємозалежності між суб'єктами регулювання, суб'єкти нижчого рівня стають об'єктами політики, що проводиться суб'єктами вищого рівня (Kolot, 2011).

Отже, особливості діяльності суб'єктів державної політики соціального розвитку на сучасному етапі та в сучасних умовах, із залученням громадського сектору, полягають у мінімізації функцій оперативного втручання в різні сфери життя, способи та форми реалізації людиною свого потенціалу. На противагу, важливим є розвиток діяльності з прогнозування, координації, стратегування соціального розвитку, створення умов для ефективного функціонування механізму саморегуляції.

\section{Перелік використаних джерел}

Boguslavska, S. I., \& Potapenko, L. V. (2013). A social policy is in the conditions of market relations. Financial space, 2(10), 106-110. [In Ukrainian]

Ilyash, O. I. (2012). Transformatsiyni sustemu natsionalnoi bezpecu Ukrainu. [Transformations of the system of social safety of Ukraine: regional measuring]. Lviv: PAIS. 592 p. [In Ukrainian].

Kogut, V. I. (2015). Factors of forming of models of social policy are in the context of problem of co-operation of state and non-state organizations of social sphere. Teoriia ta praktyka derzhavnoho upravlinnia i mistsevoho samovriaduvannia, 1, 31-34. [In Ukrainian].

Kolot, A. M. (2011). Asymmetries of development of sociallabour sphere: foreign experience and domestic realities. Ukraine: aspects of labour, 8, 3-11. [In Ukrainian].

Makarova, O. V. (2015). Sotsialna polituka v Ukraini. [A social policy is in Ukraine]. Kyiv: In-t demohrafii ta sotsialnykh doslidzhen im. M. V. Ptukhy NAN Ukrainy. 244 p. [In Ukrainian].

Orlova, N. S., Sabina, N. Yu., \& Verovina, I. M. (2014). Sotsialni aspect economichnogo rozvutcu Ukrainu. [Social aspects of economic development of Ukraine]. Donetsk. 200 p. [In Ukrainian].

Tcach, O. (2013). Features of public social policy are in the field of social development of Ukraine. Ukrainian scientific magazine "Osvita Rehionu", 2, 53-58. [In Ukrainian].

Umanciv, Y. M., Minyilo, O. I., \& Kosik, V. I. (2010). Mechanizm economichnoi politucu. [Mechanism of economic policy]. IvanoFrankivsk. [In Ukrainian].

М. А. Кальницкая,

Ужгородский национальный университет, г. Ужггород, Украина

\section{СУБЪЕКТЫ РЕАЛИЗАЦИИ ГОСУДАРСТВЕННОЙ ПОЛИТИКИ СОЦИАЛЬНОГО РАЗВИТИЯ}

Рассмотрены субъекты реализации государственной политики социального развития. Ввиду эффективности реализации государственной политики социального развития важной является характеристика тех институций, которые разрабатывают и внедряют социальные программы. Отмечено, что объекты и субъекты государственной политики социального развития характеризуются разнообразием, а их особенности зависят от многих факторов. Рядом с существованием мощного социального института в лице государственных органов важным для улучшения государственной политики социального развития является повышение роли негосударственных организаций. Определена особенность влияния деятельности общественных организаций на реализацию государственной политики социального развития. Если на макроуровне главным субъектом государственной политики социального развития выступает государство, то на мезоуровни - органы региональной власти, а на микроуровне - лицо и семья. При существовании иерархической взаимозависимости между субъектами регуляции субъекты низшего уровня становятся объектами политики, которая проводится субъектами высшего уровня. Сделан вывод о том, что социальная политика является одной из важнейших функций любого государства, а особенности деятельности субъектов государственной политики социального развития, на современном этапе и в современных условиях, с привлечением общественного сектора, заключаются в минимизации функций оперативного вмешательства в разные сферы жизни, способы и формы реализации человеком своего потенциала.

Ключевые слова: субъект; государственная политика; социальное развитие; государственные органы; социальные программы; негосударственные организации. 
M. A. Kalnutska

Uzhhorod National University, Uzhhorod, Ukraine

\section{SUBJECTS OF IMPLEMENTATION OF PUBLIC POLICY OF SOCIAL DEVELOPMENT}

The authors have examined the subjects of implementation of public policy of social development. The description of the institutions developing and implementing the social programs is important considering the efficiency of implementation of public policy of social development. We have indicated that objects and subjects of public policy of social development are characterized as being various, and their features depend on many factors. Next to existence of powerful social institute in the person of public organs important for the improvement of public policy of social development is an increase of role of non-governmental organizations. We have specified the features of influence of public organizations activity on implementation of public policy of social development. At the macro level the state acts as the main subject of the state social development policy, however on the meso level the regional authorities, and at the micro level the person and family are the main subject. Due to the existence of a hierarchical interdependence between subjects of regulation, subjects of the lower level become objects of the policy conducted by subjects of a higher level. Public policy of providing social development is proved to be above all things stressing not on imposing of a certain model, but on conditioning for the valuable bringing in every citizen to forming civil society, where balance is between interests of citizen and state, and man is in a position to be thus delivered from dependence on the state structures. Thus, we have come to the conclusion that a social policy is one of the major functions of any state, and features of the activity of subjects of public policy of social development in the modern stage and in modern terms, with bringing in public a sector, consists in minimization of functions of operative interference with different spheres of life, methods and forms of realization of the potential of man.

Keywords: subject; public policy; social development; public organs; social programs; non-governmental organizations. 